\title{
E-Marketplace Usaha Mikro Kecil Dan Menengah (UMKM) Catering Untuk Wilayah Jakarta
}

\author{
Andi Saryoko', Lutfiyah ${ }^{2}$ \\ ${ }^{1}$ Sekolah Tinggi Manajemen Informatika dan Komputer Nusa Mandiri \\ e-mail: andi.asy@nusamandiri.ac.id \\ ${ }^{2}$ Sekolah Tinggi Manajemen Informatika dan Komputer Nusa Mandiri \\ e-mail: llutfiyah49@gmail.com
}

\begin{abstract}
Abstrak - Banyak sistem dan aplikasi yang dibuat untuk membantu dan mempermudah suatu kegiatan. Begitu pula dengan sistem pemesanan dan fasilitas pemesanan catering yang juga memanfaatkan perkembangan teknologi saat ini. Proses pemesanan dan penyampaian informasi tentang catering untuk wilayah jakarta masih sederhana promosinya hanya dari mulut ke mulut, dari kenalan pribadi, atau pemasaran melalui brosur kepada calon pelanggan yang pasarnya akan lebih sempit dibandingkan dengan media internet. Saat ini, belum ada situs e-marketplace yang mengkhususkan bisnis di bidang kuliner catering. Sehingga produk mereka belum dapat dikenal banyak masyarakat, dan sarana promosi produknya yang bersifat konvensional yang hanya melalui brosur, kartu nama atau mulut kemulut. Dengan begitu, adanya e-marketplace catering dapat membuka peluang bagi para pengelola catering dalam memasarkan produknya kepada masyarakat luas melalui situs website. Model Pengembangan sistem yang digunakan untuk merancang dan mengembangkan aplikasi ini adalah waterfall model. Dan sistem e-marketplace catering ini dirancang dan dikembangkan menggunakan bahasa pemprograman PHP, HTML, CSS dengan menggunakan Database Mysql. Dengan adanya sistem e-marketplace dapat mempermudah usaha catering untuk mempromosikan produknya kepada masyarakat luas dan pempermudah pelanggan untuk mencari informasi catering secara efektif dan efisien. Dengan menggunakan sistem e-marketplace memudahkan bagi para pengelola catering dalam mengelola pendataan produk dan mengelola data transaksi dalam melayani pelanggan.
\end{abstract}

\section{Kata Kunci: E-Marketplace, catering, Website, Perkembangan Teknologi, HTML}

Abstract - Many systems and applications are made to help and simplify an activity. Likewise with the ordering system and catering ordering facilities which also take advantage of current technological developments. The process of ordering and conveying information about catering for the Jakarta area is still simple, the promotion is only by word of mouth, from personal acquaintances, or marketing through brochures to prospective customers whose market will be narrower than the internet media. Currently, no e-marketplace site specializes in catering businesses. So that their products have not been known to many people, and their conventional means of product promotion are only through brochures, business cards, or mouths of mouths. That way, the existence of e-marketplace catering can open up opportunities for catering managers in marketing their products to the wider community through the website. The system development model used to design and develop this application is the waterfall model. And this e-marketplace catering system was designed and developed using the programming language PHP, HTML, CSS using the Mysql Database. With the e-marketplace system, it can make it easier for catering businesses to promote their products to the wider community and make it easier for customers to find catering information effectively and efficiently. Using the e-marketplace system makes it easier for catering managers to manage product data collection and manage transaction data in serving customers.

Keywords: E-Marketplace, catering, Website, Technology Development, HTML

\section{PENDAHULUAN}

Perkembangan dibidang teknologi informasi membawa dampak positif bagi dunia, bahkan menjadi hal penting bagi dunia bisnis, perusahaan maupun instansi pemerintah. Demikian pula bisnis online yang menjadi tuntutan dalam dunia bisnis. Dengan perkembangan teknologi informasi dan komunikasi ini dapat dilihat dari populernya koneksi internet. Internet merupakan jaringan global diseluruh dunia yang digunakan sebagai media informasi dan komunikasi secara mendunia, untuk memungkinkan jutaan jaringan terhubung satu sama lain dengan mudah. Oleh karena itu internet sangat bermanfaat untuk kebutuhan bisnis, termasuk dalam bidang bisnis kuliner catering. 
UMKM (Usaha Mikro, Kecil, dan Menengah) merupakan sektor usaha yang saat ini diminati oleh konsumen di Indonesia. Harga yang terjangkau, menjadikan usaha-usaha kecil digandungi oleh masyarakat diseluruh lapisan. Produk yang tidak jauh berkualitas dan harga yang pas di kantong konsumen dapat membuat UMKM selalu dicari (Setiawan, Iwan, Saepudin Nirwan, 2018).

Usaha catering adalah salah satu jenis usaha mikro bisnis rumahan yang menerapkan cara praktis dan efisensi waktu bagi mereka yang membutuhkan berbagai makanan tanpa mengelolanya sendiri ataupun menyediakan peralatan acara karena membutuhkan tenaga, dana dan waktu yang besar. Usaha ini menawarkan makanan untuk berbagai kebutuhan acara seperti pesta, kantoran, seminar dan lainnya.

Proses pemesanan dan penyampaian informasi tentang catering untuk wilayah jakarta masih sederhana promosinya hanya dari mulut ke mulut, dari kenalan pribadi, atau pemasaran melalui brosur kepada calon pelanggan yang pasarnya akan lebih sempit dibandingkan dengan media internet. Dalam proses pemesanannya melalui telepon atau datang ketempat, sehingga dapat menyita banyak waktu bagi konsumen yang kediamannya jauh dari lokasi catering yang dituju. Para usaha catering merasa cara tersebut kurang efisien dikarenakan ketika ada menu baru yang ingin diinformasikan harus kembali membuat dan mengirimkan brosur baru kepada calon pelanggan.(Asyifa \& Noprisson, 2019)

Untuk mengatasi permasalahan diatas, aplikasi marketplace dapat dijadikan solusi dalam membantu para bisnis di bidang kuliner catering. Pada saat ini, belum adanya situs e-marketplace yang mengkhususkan pada bisnis di bidang kuliner catering. Sehingga produk mereka belum dapat dikenal banyak masyarakat, dan sarana promosi produknya yang bersifat konvensional yang hanya melalui brosur, kartu nama atau mulut kemulut. Dengan adanya sistem e-marketplace ini diharapkan keamanan, kecepatan, keakuratan dan kecepatan yang dapat membantu para usaha catering dalam mengelola dan menerima pemesanan secara online.

\section{Model Pengembangan Sistem}

Model pengembangan sistem yang penulis gunakan adalah SDLC (system Development Life Cycle) dengan model Structure Design waterfall, yaitu sebuah model proses pengembangan perangkat lunak yang setiap tahapannya digambarkan mengalir kebawah. Tahapan yang dilalui penulis meliputi perencanaan, analisa, perancangan, implementasi, uji coba dan maintenance (Andrean, Muhammad. Eka Saputra, 2017).

\section{A. Analisa kebutuhan sistem}

Pada tahap ini, pengembangan sistem dilakukan beberapa tahapan dalam menganalisa kebutuhan software, melingkupi pelayanan, batasan, dan tujuan sistem yang ditentukan melalui konsultasi dengan user sistem.

\section{B. Desain}

Tahap pertama akan dipelajari dalam fase dan desain sistem disiapkan. Desain sistem membantu dalam perangkat keras dan sistem penyaratan dan juga membantu dalam menentukan arsitektur sistem secara keseluruhan.

\section{Code generation}

Tahap ini, dilakukan pembuatan aplikasi secara keseluruhan yang meliputi proses pengetikan kode program. Penulis menggunakan bahasa pemrograman dengan menggunakan software Xampp, Sublime text, Enterprise Arsitecture, dan MYSQL dalam pembuatan databasenya, untuk bahasa pemrograman tersebut merupakan pemrograman terpopuler yang banyak digunakan untuk menciptakan sebuat website.

\section{Testing}

Tahap ini, pengujian sistem dimana unit program atau program individual diintegrasikan atau diuji sebagai sistem yang lengkap untuk menjamin bahwa persyaratan sistem telah dipenuhi. Tahap pengujian atau testing dilakukan dengan black box testing dimana metode ini memfokuskan pada keperluan fungsional.

\section{E. Support}

Tahap ini, dilakukan pemeliharaan perangkat yang sudah jadi, dijalankan serta dilakukan pemeliharaan. pada aplikasi agar dapat berjalan dengan baik, termasuk juga di dalamnya proses pengembangan aplikasi lebih baik lagi sesuai dengan kebutuhan.

\section{Kajian Pustaka}

a. Konsep Sistem Informasi

Sistem informasi adalah sistem yang terdapat dalam suatu organisasi yang mempertemukan kebutuhan pengelolaan data transaksi harian sebagai pendukung fungsi operasi organisasi yang bersifat manajerial dengan kegiatan strategi dari suatu organisasi untuk dapat menyediakan kepada pihak luar dengan informasi yang diperlukan untuk pengambilan keputusan. (Irviani, 2017)

\section{b. Usaha Mikro Kecil dan Menengah (UMKM)}

UMKM adalah suatu bentuk kegiatan usaha yang mampu memperluas lapangan kerja dan memberikan pelayanan ekonomi yang luas pada masyarakat. UMKM berperan penting dalam proses pemerataan, 
dan meningkatkan pendapatan masyarakat, serta mendorong pertumbuhan ekonomi masyarakat dalam mewujudkan stabilitas nasional.(Hastuti, 2020)

\section{c. HTML (HiperText Markup Languange)}

HTML singkatan dari HiperText Markup Languange yang merupakan bahasa pemrograman yang digunakan untuk membuat sebuah web, dengan menampilkan berbagai informasi dalam sebuah penjelajah web internet dan pemformatan sederhana hiperteks dalam format ASCII untuk menghasilkan tampilan yang terintegerasi.(Jumardi, 2019)

\section{d. PHP (Hypertext Prepocessor)}

PHP singkatan dari Hypertext Processor yang digunakan sebagai bahasa script server-side yang dirancang untuk membuat dan mengembangkan sebuah web yang disisipkan pada dokumen HTML. Penggunaan php memungkinkan web dapat dibuat dinamis sehingga maintance situs web tersebut menjadi lebih mudah dan efisien.(Hariyanto, 2019)

\section{e. Entity Relationship Diagram (ERD)}

Entity Relationship Diagram merupakan model data yang digunakan sebagai alat untuk mendefinisikan kebutuhan database tentang suatu organisasi untuk mengorganisasikan dan mendokumentasikan data sistem. Model data ini sering disebut sebagai database, karena dapat diimplementasikan sebagai database. Selain itu model data juga sering disebut sebagai model informasi (Information Modeling).(Weli, 2019)

\section{f. Logical Relational Structure (LRS)}

Logical Relational Structure merupakan suatu model yang digunakan untuk menggambarkan struktur record-record pada tabel yang terbentuk dari hasil relasi antar himpunan entitas. Dengan menentukan kardinalitas jumlah tabel dan Foreign Key (FK). (Fridayanthie Eka Wida, 2016)

Berikut adalah cara membentuk skema database atau LRS (logical Relational Structure): (Fridayanthie Eka Wida, 2016)

1. Jika relasinya satu ke satu, maka foreign key diletakan pada salah satu dari dua entitas yang ada atau menyatukan kedua entitas tersebut.

2. Jika relasinya satu ke banyak, maka foreign key diletakan pada entitas Many.

3. Jika relasinya banyak ke banyak, maka dibuat "file konektor" yang berisi dua foreign key yang berasal dari kedua entitas.

\section{METODOLOGI PENELITIAN}

Metode penelitian adalah cara yang digunakan untuk mengumpulkan data dengan beberapa langkah. Dalam penyusunan laporan skripsi ini, penulis melakukan penelitian untuk mengumpulkan data dengan beberapa cara sebagai berikut:

A. Observasi (Observation)

Metode ini digunakan untuk mengumpulkan data-data yang diperlukan dengan cara melakukan pengamatan terhadap objek penelitian. Penulis melakukan riset dengan mengamati secara langsung proses pemesanan catering secara umum.

B. Wawancara (Interview)

Metode ini dilakukan untuk mendapatkan informasi secara lengkap penulis melakukan wawancara langsung dengan salah satu konsumen catering serta salah satu orang yang sudah berpengalaman kerja dalam bidang catering yang terkait langsung dengan proses pemesanan makanan mulai dari pengelola catering hingga konsumen.

C. Studi Kasus (Literature)

Studi kasus dilakukan cara pengumpulan data dan mempelajari dari teori-teori dengan melihat sumber kepustakaan seperti situs web, jurnal ilmiah, skripsi dan sebagainya yang dapat dipertanggung jawabkan untuk dijadikan bahan referensi dalam pembuatan aplikasi.

\section{HASIL DAN PEMBAHASAN}

\section{TAHAPAN ANALIS}

Sistem E-Marketplace adalah sistem yang memfasilitasi proses jual beli dari berbagai toko seacara online. Menyediakan tempat bagi para penjual, dan membantu penjual untuk bertemu calon pelanggan dengan mudah tanpa harus bertatap muka. Calon pelanggan dapat melakukan pembelian melalui media browser.

Berikut ini spesifikasi kebutuhan (system requement) dari sistem E-Marketplace Usaha Mikro Kecil dan Menengah (UMKM) Catering.

Halaman Pengunjung

A1. Pengunjung melihat semua produk

A2. Pengunjung melihat semua pelapak

A3. Pengunjung melihat kategori produk

A4. Pengunjung mendaftar sebagai member

Halaman Konsumen (Member)

B1. Konsumen melakukan daftar

B2. Konsumen melakukan login

B3. Konsumen memilih produk sesuai kategori

B4. Konsumen dapat melakukan pemesanan

B5. Konsumen dapat melakukan konfirmasi pembayara

B6. Konsumen dapat melakukan konfirmasi penerimaan produk

Halaman Reseller (Pelapak)

C1. Reseller melakukan daftar

C2. Reseller melakukan login

C2. Reseller mengelola data toko

C3. Reseller mengelola data produk 
C4. Reseller mengelola data transaksi

C5. Reseller melihat laporan penjualan

Halaman Admin

D1. Admin melakukan login

D2. Admin mengelola data konsumen

D3. Admin mengelola data reseller

D4. Admin mengelola data kategori produk

D5. Admin mengelola data sub kategori produk

D6. Admin mengelola data produk

D7. Admin mengelola data transaksi

\section{Use Case Diagram}

a. Use Case Diagram Halaman Konsumen

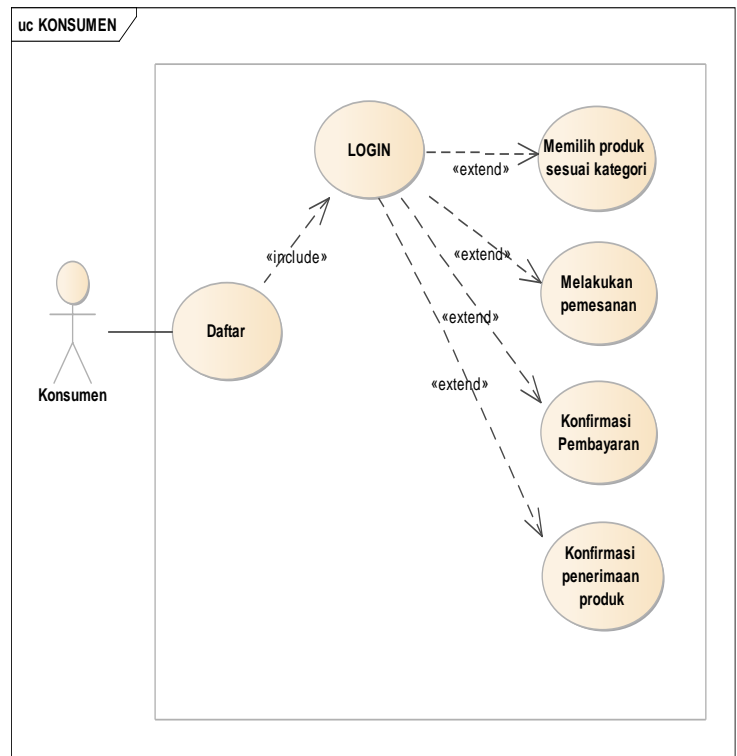

Sumber: Hasil Penelitian (2020)

Gambar 1. Use Case Diagram Konsumen

b. Use Case Diagram Halaman Pelapak

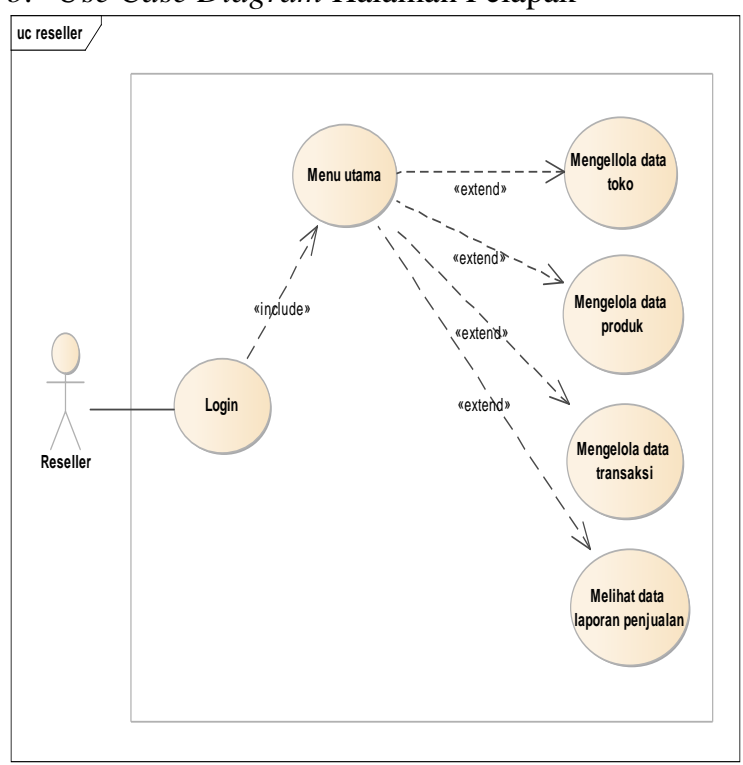

Sumber: Hasil Penelitian (2020)

Gambar 2. Use Case Diagram Pelapak c. Use Case Diagram Halaman Admin

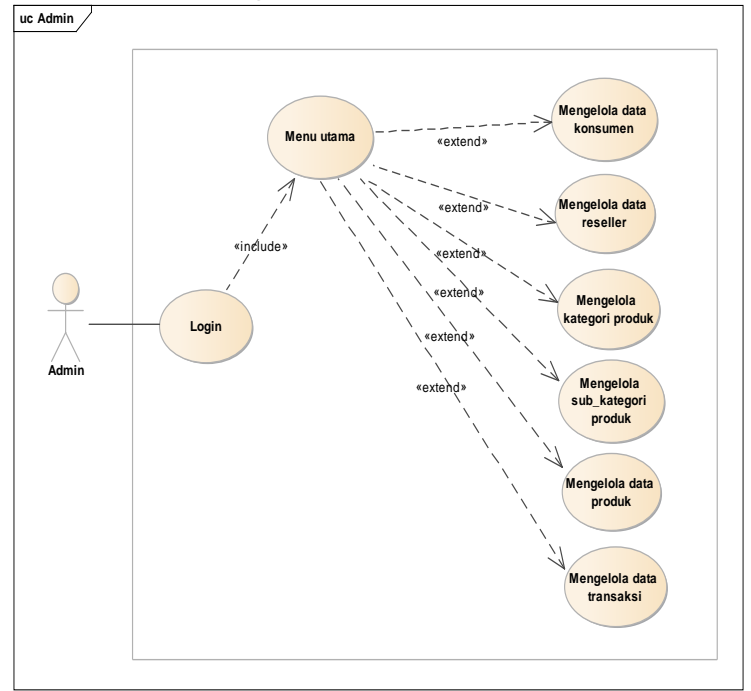

Sumber: Hasil Penelitian (2020)

Gambar 3. Use Case Diagram Admin

\section{Activity Diagram}

a. Activity Diagram Pemesanan Produk

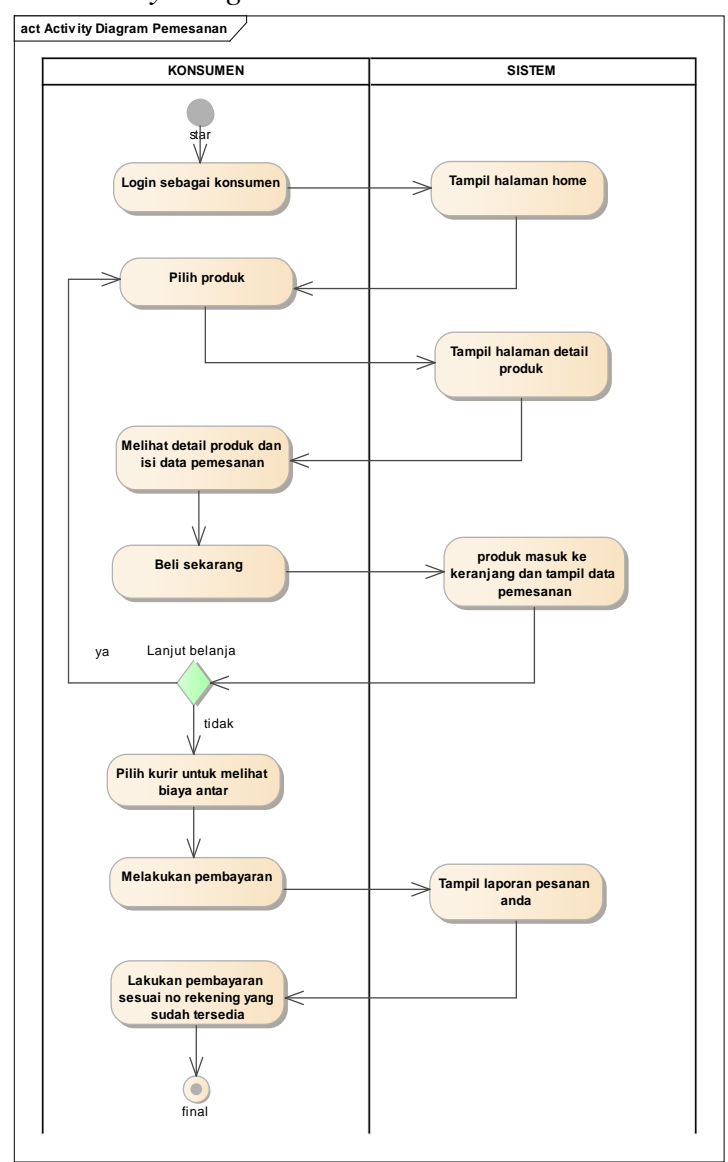

Sumber: Hasil Penelitian (2020)

Gambar 4. Activity Diagram Pemesanan Produk 
b. Activity Diagram Mengelola Data Penjualan

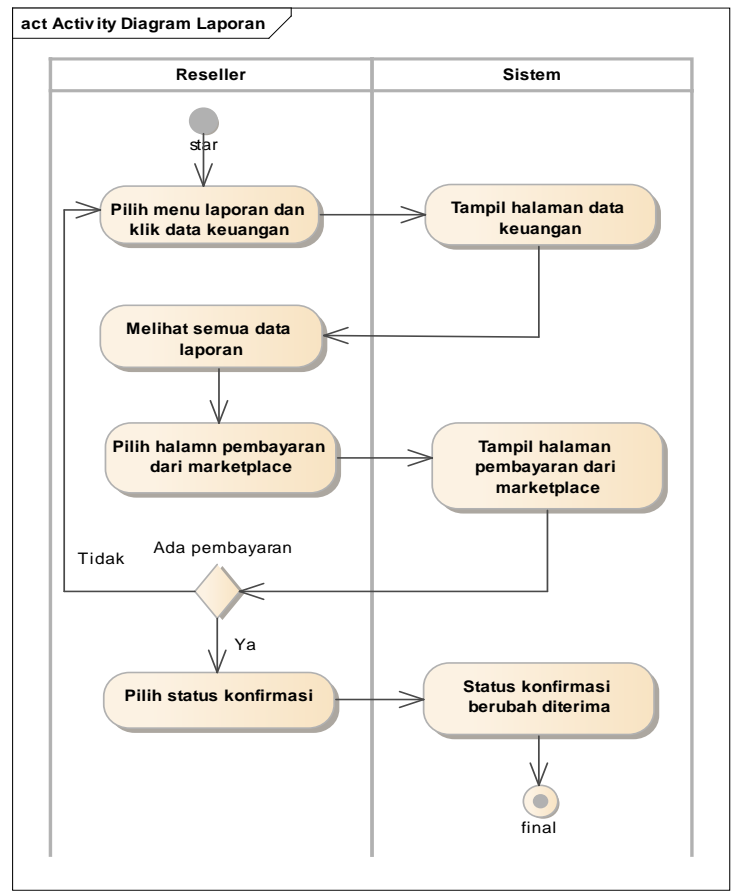

Sumber: Hasil Penelitian (2020)

Gambar 5. Activity Diagram Mengelola Data Penjualan

c. Activity Diagram Transaksi Pembayaran reseller

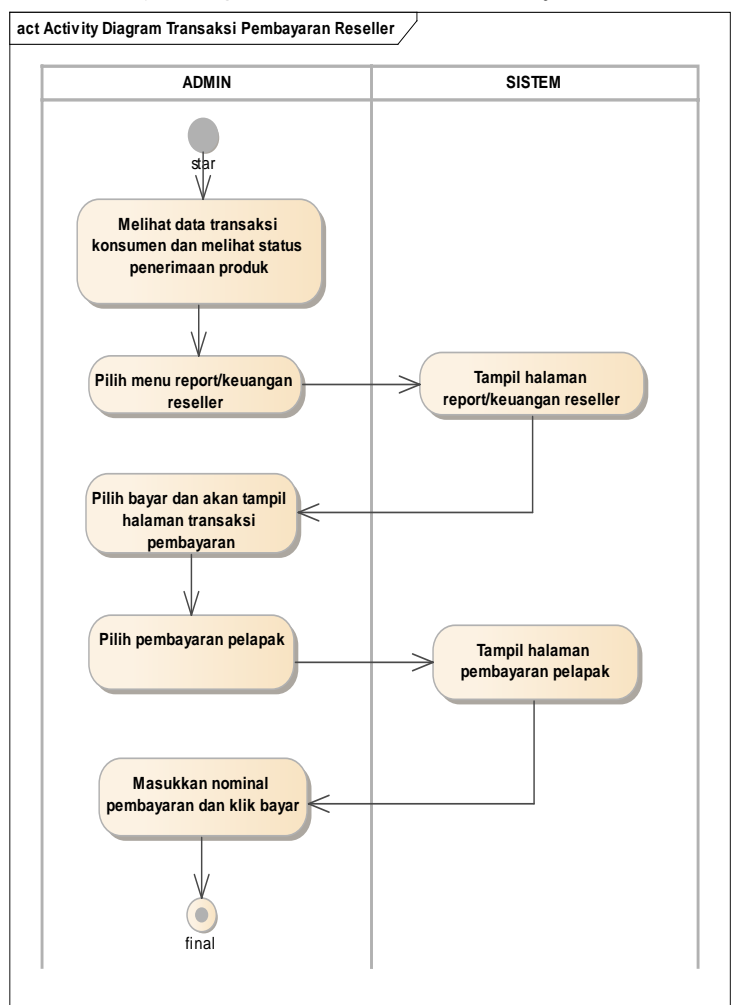

Sumber: Hasil Penelitian (2020)

Gambar 6. Activity Diagram Transaksi Pembayaran Reseller/Pelapak
4. Component Diagram

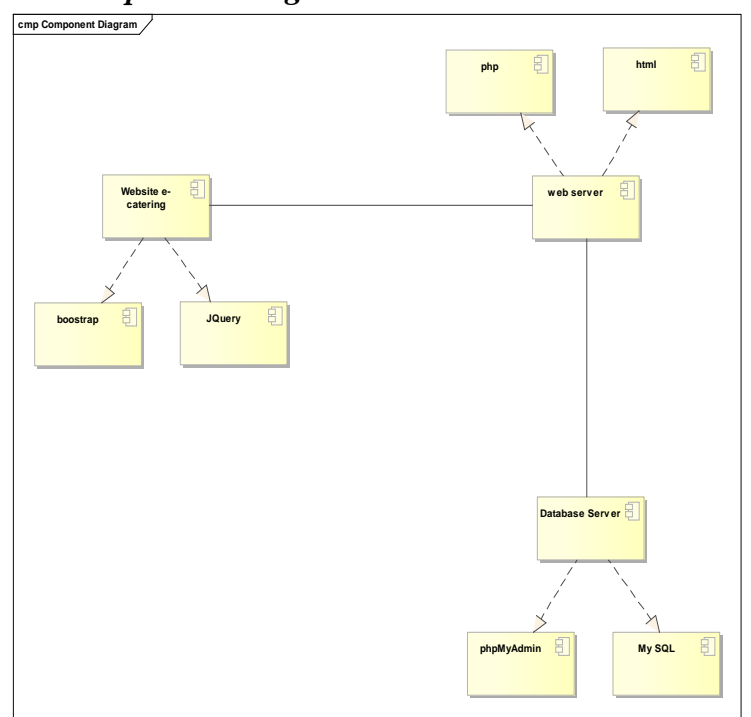

Sumber: Hasil Penelitian (2020)

Gambar 7. Component Diagram E-Marketplace Catering

\section{Deployment Diagram}

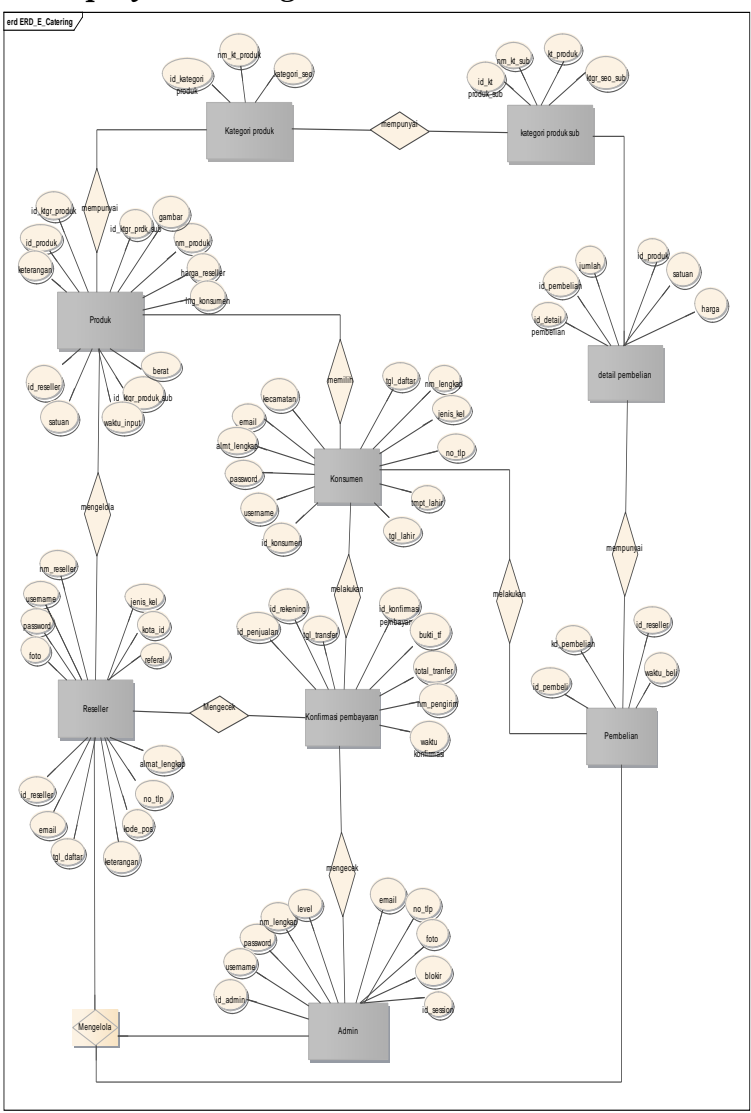

Sumber: Hasil penelitian (2020)

Gambar 8. Deployment Diagram E-Marketplace Catering 


\section{Desain Database}

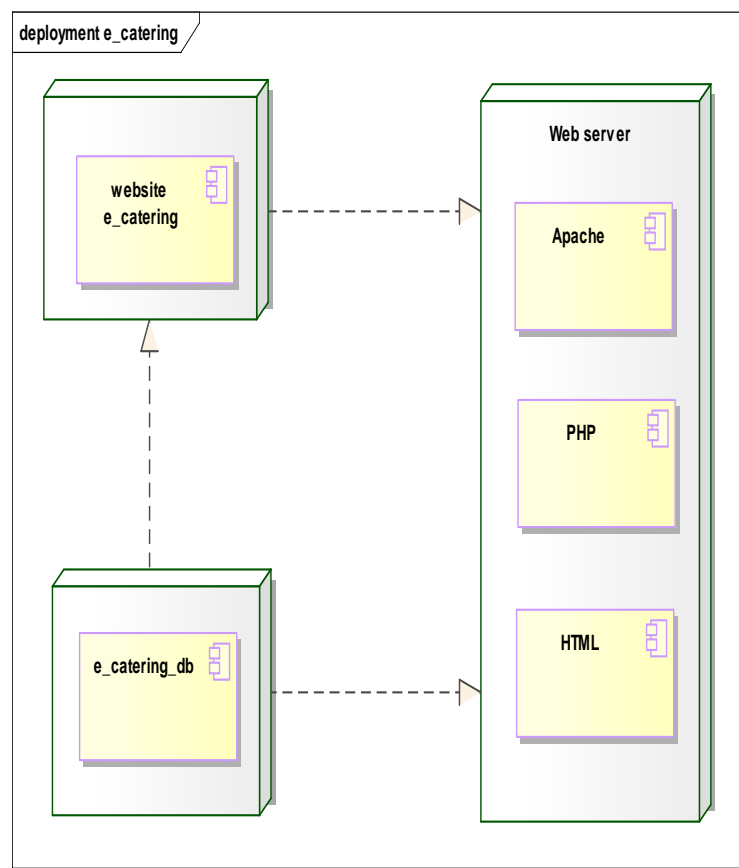

Sumber: Hasil Penelitian (2020)

Gambar 9. Entity Relation Diagram (ERD)

\section{Tampilan Program}

Suatu sistem atau aplikasi harus mempunyai desain tampilan yang menarik dan mudah difahami oleh pengguna sistem. Sehingga perlu didesain dengan baik. Pada aplikasi ini terdiri dari empat aktor yang dapat mengakses sistem e-marketplace catering yaitu pengunjung, pelanggan, reseller atau pelapak dan admin.

a. Tampilan Halaman Home

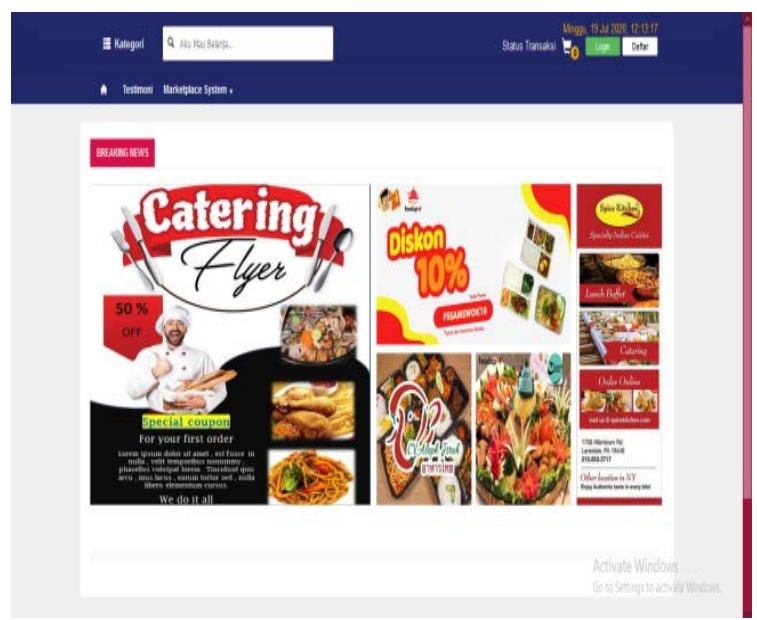

b. Tampilan Halaman Login Konsumen

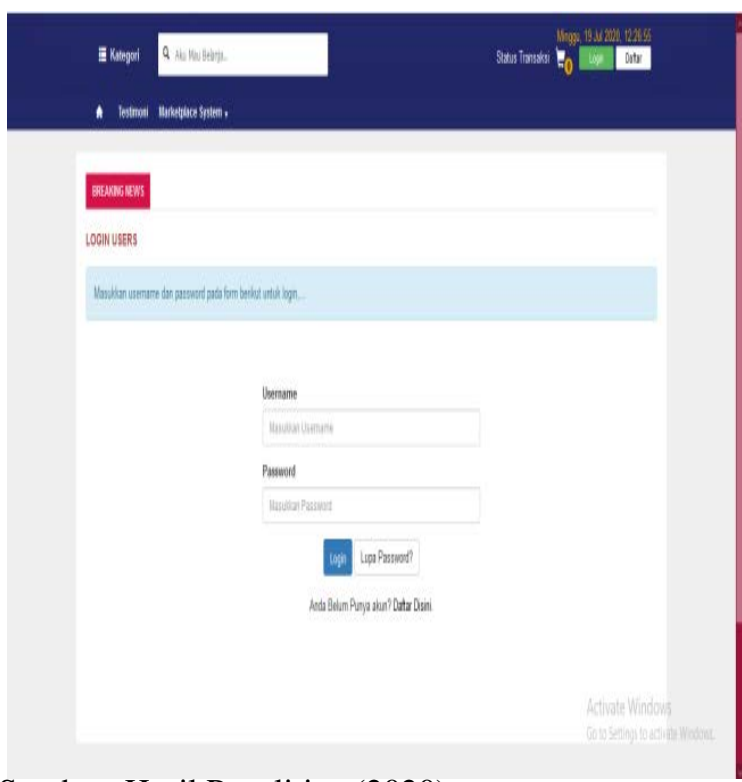

Sumber: Hasil Penelitian (2020)

Gambar 11. Tampilan Halaman Login Konsumen

c. Tampilan Halaman Data Produk

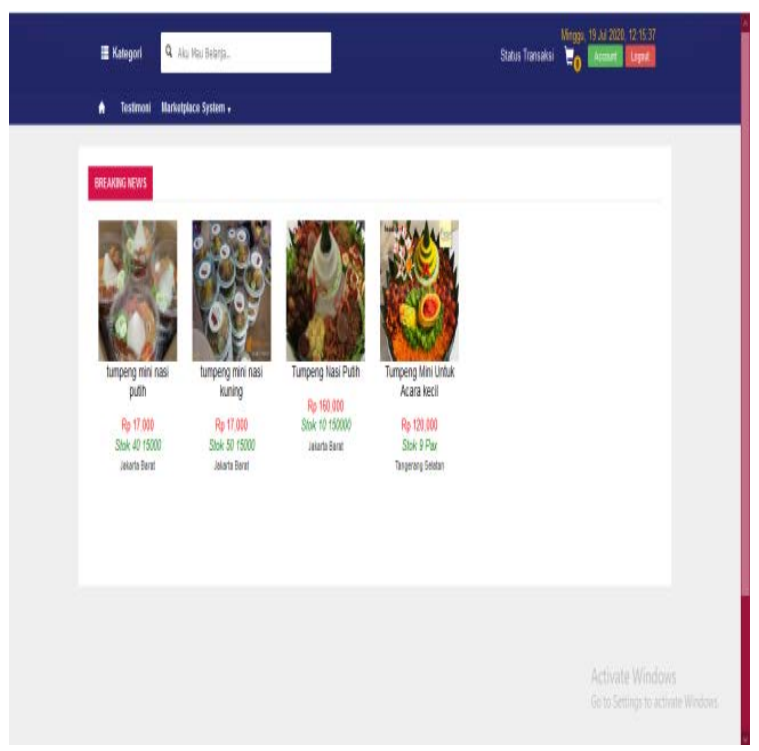

Sumber: Hasil Penelitian (2020)

Gambar 12. Tampilan Halaman Data Produk

Sumber: Hasil Penelitian (2020)

Gambar 10. Tampilan Halaman Home 
d. Tampilan Halaman Reseller/Pelapak

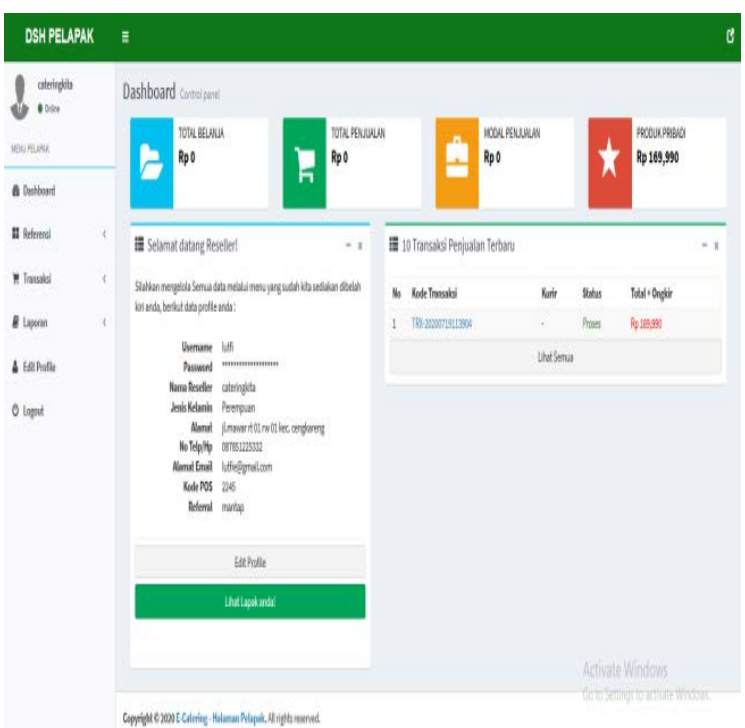

Sumber: Hasil Penelitian (2020)

Gambar 13. Tampilan Halaman Reseller/Pelapak

e. Tampilan Halaman Stok Data Produk Reseller/Pelapak

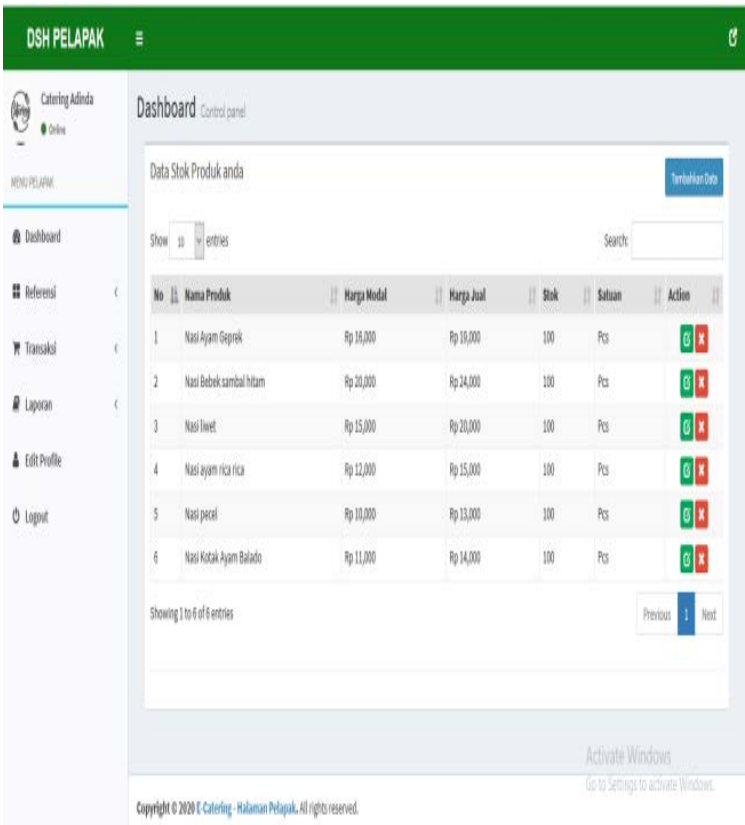

Sumber: Hasil Penelitian (2020)

Gambar 14. Tampilan Stok Barang Reseller/Pelapak f. Halaman Admin

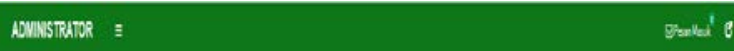

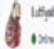

exoes

atsone

is on

0 in

Oature

Ointer

0 lempine

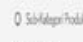

0 inhes

onemitate

0 ingly

0 ins

0 hint

Eltollem

Ftwike

7)

0 lowe

Dasthoard cunine

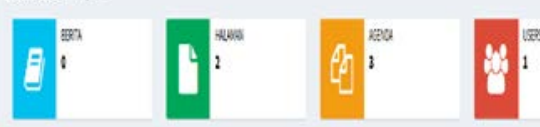

,

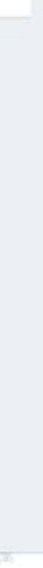

Sumber: Hasil Penelitian (2020)

Gambar 15. Tampilan Halaman Admin

g. Halaman Data Reseller/Pelapak

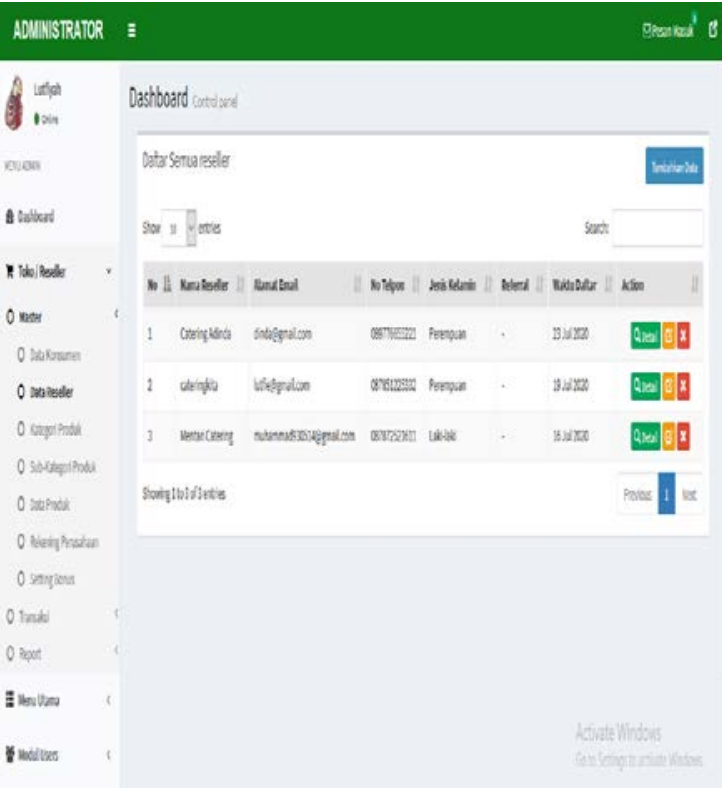

Sumber: Hasil Penelitian (2020)

Gambar 16. Tampilan Halaman Data Reseller/Pelapak 


\section{KESIMPULAN}

Berdasarkan uraian dan penjelasan pada bab-bab sebelumnya, penulis membahas mengenai pembuatan E-Marketplace Usaha Mikro Kecil da Menengah (UMKM) Catering.Dengan adanya $e$ marketplace catering dapat membuka peluang bagi para pengelola catering dalam memasarkan produknya kepada masyarakat luas melalui situs website.Sistem e-marketplace ini ternyata lebih efektif dan memberi kemudahan bagi pelanggan dalam mencari informasi catering dan melakukan pemesanan produk catering dalam satu aplikasi. Dengan menggunakan sistem e-marketplace ini memudahkan bagi para pengelola catering dalam mengelola pendataan produk dan mengelola data transaksi dalam melayani pelanggan. Sistem emarketplace dapat diakses darimana saja dan kapan saja. Adapun kekurangan dari sistem e-marketplace catering ini yaitu sistem pemesanannya dalam satu transaksi tidak dapat melakukan pesanan dari dua toko yang berbeda.

\section{REFERENSI}

Andrean, Muhammad. Eka Saputra, T. S. (2017). Perancangan Dan Implementasi Sistem Informasi E-Marketplace Untuk Katering. Jurnal Teknologi Informasi, 5(2), 294-303.

Asyifa, R. V., \& Noprisson, H. (2019). Perancangan Sistem Informasi Pemesanan Catering Berbasis Web (Studi Kasus Catering Ny. Eva ). Jukomika, 2(3), 90-97.

Fridayanthie Eka Wida, dan M. T. (2016). Rancang Bangun Sistem Informasi Permintaan ATK Berbasis Intranet (Studi Kasus: Kerjaksaan
Negeri Rangkasbitung). IV(June), 126-138.

Hariyanto, K. dan H. P. (2019). sistem Monitoring Lulusan Perguruan Tinggi Dalam Memasuki Dunia Kerja Menggunkan Tracer Study (S. H. Lutfiah, ed.). Surabaya: Media Sahabat Cendekia.

Hastuti, P. N. A. dan A. P. (2020). Kewirausahaan dan UMKM (A. Rikki, ed.). Medan: Yayasan Kita Menulis.

Irviani, R. dan E. Y. A. (2017). Pengantar Sistem Informasi (E. Risanto, ed.). Yogyakarta: CV. ANDI OFFSET.

Jumardi, R. (2019). WEBSITE STATIS Konsep dan peraktik HTML - CSS. Ponorogo: Uwais Inspirasi Indonesia.

Setiawan, Iwan, Saepudin Nirwan, F. M. A. (2018). Mikro , Kecil , Dan Menengah Berbasis Web. 10(3), 37-43.

Weli. (2019). Aplikasi Kasus Siklus Transaksi Bisnis (K. Sihotang, ed.). Jakarta: Universitas Katolik Indonesia Atma Jaya.

\section{PROFIL PENULIS}

Lutfiyah, S.Kom., Lahir di Bangkalan, 16 Juni 1998. Mahasiswa STMIK Nusa Mandiri Jurusan Sistem Informasi.

Andi Saryoko, M.Kom., Sebagai dosen pada STMIK Nusa Mandiri dan Universitas Bisa Sarana Informatika. 